\title{
Reform and Practice of the Comprehensive Training Platform of Financial Management Major in Universities
}

\author{
Xiaofang $\operatorname{Tan}^{1, \text { a }}$, Xiaohua Zhan ${ }^{1, \text { a }}$, Yilin $\mathrm{Pan}^{1, \text { a }}$, Shenglan $\mathrm{Hu}^{1, \text { a }}$ \\ ${ }^{1}$ Transportation Management College, Dalian Maritime University, Dalian, 10026, China \\ aemail: txfzfy@163.com
}

Keywords: Financial Management Major; Comprehensive Training Platform; Reform; Universities

\begin{abstract}
The comprehensive training platform of Financial Management Major is a multi-functional professional education center integrating teaching practice and technical service,. The paper takes the practice courses of Financial Management Major as the research object, and analyzes the shortcomings of the current training courses and the necessity to improve it. In addition, this paper also introduces the thought and the framework of the efficient comprehensive training platform.
\end{abstract}

\section{Introduction}

Financial Management Major is a new specialty with vast prospects. In 1998, the Ministry of Education decided to set up the Financial Management Major so as to adapt to the need for financial analysis and financial decision of the market economy. Despite the Financial Management Major is a new branch of the formal subject, it has become one of the most energetic management subjects of the wide Business Administration.

In recent years, although many colleges and universities pay enough attention on the practical teaching of the Financial Management and take an active part in advancing it, however, the practical teaching is seriously difficult to go deep into the enterprises because of the sensibility of the financial work. As a result, the true practical teaching is absent in the real environment and it's not good for the development of the financial students' professional skills. At the present time, the graduates of the Financial Management Major generally can't adapt to the need of the society economy. For them, it's not easy to find a job and the promotion of personal professional abilities is also restricted. Therefore, building a comprehensive training platform to change the current education mode of the university may be an efficient way to solve this problem.

\section{Literature Review}

Under the background of internationalization of the global economy, to contribute the financial management education of universities to coincide with internationalization and social needs, the universities at home and abroad had reformed their financial management teaching system fundamentally. Among them, the most representative revolution road reflects on the following tips:

Change of educational objectives. The American Accounting Association (AAA) set up the Accounting Education Change Commission (AECC) in 1989, the first bulletin of AECC said: The purpose of accounting teaching in school lies in cultivating the qualities that a specialist should own rather than train the students to be specialists when they are graduated. Elliott [1] held the view that the function of the higher education is training knowledge workers and accounting educators must teach students how to learn rather than what to learn. Different from foreign education of clear objectives, how to position undergraduates' financial management education objectives is still not resolved in China, which is still at the stage of accounting talent cultivation of "professionals" and "generalist" battle phase. Yan Dawu [2] considered that the goal of accounting education should be cultivating specialists for actual work departments. Liu Yongze and Sun Guangguo[3] considered that we should carry through classified education according to students' different choice about graduating to work or to continue study and the actual situation. Nevertheless, this classification 
requires all students' specific self-development position may be unpractical at present.

Variation of teaching methods. Abrecht and Sack [4]claimed that the financial education should teach the students how to look for the answer and how to learn. What they lied stress on was the courses with high level and wide caliber rather than deep-going professional education. Richard [5]found that using Team Model in the accounting teaching could help the students not only increase the knowledge about interpersonal relationship and teamwork skills in the financial work but also prepare for dealing with unconventional accounting problems. Different from the foreign mode that claims process education and student-center, undergraduate accounting education in China still emphasizes the result and teacher-center. More and more schools and scholars begin to discuss the teaching methods, such as practice base, simulation teaching and so on. However, practical teaching is still at groping stage and there is no successful model.

Transform of the curriculum design. Patten and Williams [6] suggested the accounting education should be based on the multidisciplinary knowledge. Niu Yanxiu[7]discussed the content-cross problem of Management Accounting, Cost Accounting and Financial Management, and analyzed the keys and differences of the combined Cost Management and Financial Management. Meng Yan and Li Ling[8] had made a survey and found such problems, such as the content repetition of undergraduate accounting major, disorder of the proportion of basic course and specialized course, some omissions in the curriculum provision and so on.

As the economic leading province in northeast China, the higher education of Liaoning province is also in a higher level in the whole country. However, in forty universities in Liaoning province, the undergraduate education of financial management major also exists some problems, such as unclear education goal, stiff and curing teaching method, dispersed curriculum system and so on. Therefore, considering to the reality, the training objective of financial management major is separated from the economic and social demand for talents quality of Liaoning province, the following text will take the $\mathrm{ABC}$ university in Liaoning province as the object, and discuss the necessity, system components and practical operation of establishing the comprehensive training platform of Financial Management Major.

\section{Current Situation of The Comprehension Training Platform of Financial Management Major}

In 2011, the financial management major's faculty conduct a comprehensive revision to the undergraduate program, agreed to add multiple practice teaching. The new training plan pays more attention to actual operation, at the same time also puts forward higher requirements for laboratory conditions. However, the existing experimental conditions can only meet the demand of the traditional practice teaching, relative to the new training mode, there are more shortages.

Classroom practice teaching is lack of a real practical training content. The current practice and theory courses are included in the same course, when the teachers are in teaching, limited to the teaching practice, teaching venue and equipment constraints, the practice teaching mainly takes the form of case analysis, project discussion. There is lack of a real practical training content, or only small simulation training. The teaching form cannot really combine enterprise's actual operation pattern, from the perspective of enterprise talent demand with training courses.

Off-campus practice base becomes a mere formality. Look from the result of the long-term operation, the role of off-campus practice bases are mainly for providing cognition practice, which don't really give students practice environment. Financial information is important because which relate to the development of a company; as a result, companies tend to not accept interns to work in the real financial. Students going to the internship units, their more job are typing, photocopying, or odd jobs, it is difficult for students to participate in the enterprise financial work. The mere formality practice brought vicious circle, students feel that internship is meaningless, they don't want to waste their time; Firms find internship students have no value, but a kind of burden, which are not willing to accept them.

The laboratory equipments are not suitable for financial comprehensive training needs. During the comprehensive training curriculum of financial management major, the most basic link is doing manual account statement. Early internship link need to handle a large number of vouchers, books 
and statements, students need simulate rotation internship. And the later internship link need computer as a tool, with the aid of certain financial software. These features bring forward the request laboratory is capacious, desks and chairs can be moved freely, tables, chairs, computers and other equipments can be combined and separated freely.

\section{Necessity of Constructing Integrated Training Platform of Financial Management Major}

Talents training goal orientation calls for practice course. According to the specialized requirements of market for the company's financial professionals, Financial Management Major cultivate professional talents in these fields. The talent training goal of Financial Management Major determines the characteristics of the course system setting, which emphasizes on practical and operation ability. Therefore, the domestic many colleges and universities are beginning to find training mode to satisfy the needs of the society.

Comprehensive laboratory has become a necessary part of financial management major. In recent years, under the baton of employment guidance, each college and university has made variety of ways to improve the training of the students' employment and entrepreneurship. For Financial Management Major, the most typical is the construction of laboratory, the laboratory of Financial Management Major developing very rapidly. The experience of other colleges and universities provides us with reference to the experience, also convey a kind of information which means comprehensive laboratory construction is urgent in Financial Management Major of colleges and universities.

National demonstration course project needs the support of experimental base. The "Financial Management" course won the "National Bilingual teaching Demonstration Course" in 2010. State provided financial support for the project. Through setting up the bilingual demonstration course base of Financial Management Major, which will drive more teachers to participate in the bilingual teaching course construction, and improve the quality of bilingual teaching. Therefore the subsequent construction of National Bilingual teaching Demonstration Course needs test base to strongly support.

\section{Construction of Comprehensive Training Platform of Financial Management Major}

Comprehensive training platform is not a simple simulate laboratory to meet the student's internship, but a comprehensive base that has the function of integrating multidisciplinary knowledge, meeting the demand of multi-level training and combining production with research as one. As a result, the idea of the construction of integrated training platform of Financial Management Major will be: curriculum practice $\rightarrow$ major practice $\rightarrow$ comprehensive practice.

Construction principle. Comprehensive training platform will undertake the multiple tasks like discipline construction, scientific research, teaching research and development, practice teaching and so on. Its basic principle is according to Financial Management Major's development planning, to construct the soft environment of simulate laboratory. Making great efforts to meet the experimental teaching requirements, provide places for teachers to prepare lessons, and become the teaching experiment base.

Construction orientation. Comprehensive training platform of Financial Management Major will achieve the target of combining processing technology of accounting theory, computer accounting information, computer auditing, with financial investment by the means of information science and technology. The laboratory aims to established experimental project for the campus students, and then that has will be transferred into a new financial internship base of simulate social experiment teaching, online training, identification of professional qualification and professional skills certificate test .

Composition of the comprehensive training platform. Comprehensive training platform of Financial Management Major mainly includes four parts, the transition from creating manual accounting, cost accounting to the accounting computerization; From the basic accounting business extended to multi-dimensional economic activities like audit, tax, investment, foreign exchange and 
so on; From work table and the basic financial analysis of financial management, to the financial management training and individual experiments mastering, gradually transit to the comprehensive experiments of financial decision-making including analysis of financing, investment, mergers and acquisitions, simulating more complicated financial management activities, and making the simulation more realistic. According to the latest training plan of Financial Management Major, the future of the comprehensive training has the following eight courses (see Table 1).

TABLE I. TRAINING COURSES

\begin{tabular}{|c|c|c|}
\hline No. & Practical Courses & Realization Form \\
\hline 1 & Business Investment & Computer simulation \\
\hline 2 & Exchange Transaction & Computer simulation \\
\hline 3 & Finacial Software & Computer simulation \\
\hline 4 & Payment Tax Audit & $\begin{array}{l}\text { Manual simulation } \\
\text { Computer simulation }\end{array}$ \\
\hline 5 & Personal Finance & Computer simulation \\
\hline 6 & Business Plan & Computer simulation \\
\hline 7 & Cost Accounting & Manual simulation \\
\hline 8 & Finance Accounting & Manual simulation \\
\hline
\end{tabular}

\section{Acknowledgement}

The result is supported by "twelfth five-year" plan project of Education-Scientific Planning Foundation of Liaoning Province (Project No. JG11DB032), and is the part of the works of Education Reform Project of Dalian Maritime University (Project No. 2011Y10, 2011Y11).

\section{References}

[1] Elliott Sober. Reconstructing the Past: Parsimony, Evolution and Inference [M]. MIT Press ,1991(4): 43-78.

[2] Yan Dawu. Wang Huacheng. Zhang Ruijun. Reform about Accounting Class Curriculum and Teaching Content in 21st Century. Chinese Accounting Professor Annual Meeting, Beijing, 1998. [3] Liu Yongze. Sun Guoguang. Xinhe. Current situation and Countermeasures about accounting education and accounting education research. Accounting study [J]. 2004(2): 75-81

[4] Albrecht, W. and R. Sack, 2000, Accounting Education: Charting the course through a Perilous Future, Accounting education series \#16, Sarasota, FL: American Accounting Association.

[5] Richard S. Sathe(2009), Using the cohort mod el in accounting education, Accounting Education, Volume 18(1):33-49.

[6]Patten RJ, Williams DZ. There's trouble-right here in our accounting programs: the challenge to accounting educators. Issues Acc Educ 1990;5(2):175-9.

[7] Niu Yanxiu. Content cross among anagement accounting, cost accounting and financial management. Accounting research [J], 2002(6): 40-41.

[8] Yan Meng. Ling Li. Accounting Undergraduate Course System Reform Under Market Orientation-Based on the practice of Chinese colleges and universities, survey evidence. Accounting research $[\mathrm{J}], 2007(3)$ : 55-63. 